\title{
Respons Pertumbuhan dan Produksi Tanaman Jagung Manis Terhadap Aplikasi Biochar dan Pupuk Organik Cair
}

Growth Response and Production of Sweet Corn Crop by Application of Biochar and Liquid Organic Fertilizer

\author{
Domas Mesiekiel Simanjuntak*, Nini Rahmawati, Rosita Sipayung \\ Program Studi Agroteknologi Fakultas Pertanian USU Medan 20155 \\ *Corresponding author: mesiekield@gmail.com
}

\begin{abstract}
This research was carried out in the research area of Balai Benih Induk Tanjung Selamat, at Pendidikan Road of Tanjung Selamat, Medan Tuntungan, Medan at altitude $\pm 35 \mathrm{~m}$ asl. This experiment was conducted from October to December 2016. The experimental method used was factorial randomized block design (RBD) with 2 factors of treatment ie the dose of biochars ie control, 5 ton/hectare, 10 ton/hectare, and 15 ton/hectare and concentration of liquid organic fertilizer ie control, $5 \mathrm{ml} /$ liter of water, $10 \mathrm{ml} /$ liter of water, $15 \mathrm{ml} /$ iter of water. The results showed that the biochar treatment had significant effect on root volume variables, production per sample and production per plot, the best dose of biochar is 15 ton/hectare. Liquid organic fertilizer treatment significantly affect the variables observed leaf area, root volume and production per plot, the best concentration of liquid organic fertilizer is $15 \mathrm{ml} /$ Liter of water while the interaction between the treatment of liquid organic fertilizer and biochar treatment had no significant effect on all observed variables.
\end{abstract}

Keywords : biochar, liquid organic fertilizer, sweet corn

\begin{abstract}
ABSTRAK
Penelitian ini dilaksanakan di lahan penelitian Balai Benih Induk Tanjung Selamat, jalan Pendidikan Kelurahan Tanjung Selamat, Kecamatan Medan Tuntungan, Medan pada ketinggian tempat $\pm 35 \mathrm{~m}$ dpl. Penelitian ini dilaksanakan pada bulan Oktober sampai dengan Desember 2016. Metode percobaan yang digunakan adalah Rancangan Acak Kelompok (RAK) faktorial dengan 2 faktor perlakuan yaitu dosis biochar yaitu kontrol, 5 ton/hektar, 10 ton/hektar, 15 ton/hektar dan konsentrasi pupuk organik cair yakni kontrol, $5 \mathrm{ml} /$ liter air, $10 \mathrm{ml} / \mathrm{liter}$ air, $15 \mathrm{ml} / \mathrm{liter}$ air. Hasil penelitian menunjukkan bahwa perlakuan biochar berpengaruh nyata terhadap peubah amatan volume akar, produksi per sampel dan produksi per plot, perlakuan biochar terbaik ialah 15 ton/hektar.Perlakuan pupuk organik cair berpengaruh nyata terhadap peubah amatan luas daun, volume akar dan produksi per plot, perlakuan pupuk organik cair terbaik ialah $15 \mathrm{ml} / \mathrm{liter}$ air sedangkan interaksi antara perlakuan pupuk organik cair dan perlakuan biochar tidak berpengaruh nyata terhadap semua peubah amatan.
\end{abstract}

Kata kunci : biochar, pupuk organik cair, jagung manis

\section{PENDAHULUAN}

Hampir semua bagian dari tanaman jagung manis memiliki nilai ekonomis. Beberapa bagian tanaman yang dapat dimanfaatkan diantaranya, batang dan daun muda untuk pakan ternak, batang dan daun tua (setelah panen) untuk pupuk hijau/ kompos, batang dan daun kering sebagai bahan bakar pengganti kayu bakar, buah jagung muda untuk sayuran, perkedel, bakwan, dan 
berbagai macam olahan makanan lainnya (Purwono dan Hartono, 2007).

Kebutuhan jagung terus meningkat, baik untuk pangan maupun pakan. Dewasa ini kebutuhan jagung untuk pakan sudah lebih dari $50 \%$ kebutuhan nasional.Sementara itu produksi jagung dalam negeri belum mampu memenuhi semua kebutuhan, sehingga kekurangannya dipenuhi dari jagung impor (Suyamto et al., 2006).

Dalam upaya pengembangan jagung manis yang lebih kompetitif, diperlukan upaya efisiensi usahatani, baik ekonomi, mutu maupun produktivitas melalui penerapan teknologi mulai dari penentuan lokasi, penggunaan varietas, benih bermutu, penanaman, pemupukan yang tepat, pemeliharaan, hingga penanganan panen dan pasca panen yang tepat (BPPP, 2008).

Untuk meningkatkan produksi diperlukan pemupukan.Pupuk yang ditambahkan dapat berupa pupuk organik atau pupuk anorganik. Sebagian besar petani di Indonesia ternyata masih banyak yang menggunakan pupuk anorganik.Sementara ketersediaan pupuk anorganik di pasar, sering menjadi kendala bagi petani.Salah satu penyebabnya adalah pendistribusian yang tidak tepat waktu. Harga bahan baku yang relative mahal mengakibatkan harga pupuk anorganik juga relatif mahal. Salah satu cara untuk mengatasinya adalah dengan menggunakan pupuk organik (Simamora dan Salundik, 2006).

Pupuk organik mempunyai beberapa keunggulan, yaitu dapat meningkatkan kandungan bahan organik di dalam tanah, memperbaiki struktur tanah, meningkatkan kapasitas tukar kation tanah, meningkatkan aktivitas kehidupan biologi tanah dan meningkatkan ketersediaan hara di dalam tanah.Pupuk organik mengandung asam humus yang membantu membebaskan unsurunsur yang terikat, sehingga mudah diserap oleh tanaman (Hasibuan, 2006).

Keuntungan penggunaan pupuk daun antara lain, respon terhadap tanaman sangat cepat karena langsung dimanfaatkan oleh tanaman dan tidak menimbulkan kerusakan pada tanaman, dengan catatan aplikasinya dilakukan secara benar. Sebenarnya, kandungan unsur hara pada pupuk daun identik dengan kandungan unsur hara pada pupuk majemuk. Hanya saja, faktor sifat fisik dan sifat kimia tanah tidak dijadikan sebagai faktor utama. Sebagai faktor utamanya adalah manfaat tiap unsur hara yang dikandung oleh pupuk daun bagi perkembangan dan peningkatan hasil panen (Novizan, 2001).

Permasalahan yang dihadapi sekarang adalah, kandungan bahan organik dalam tanah semakin lama semakin berkurang, bahan organik sering disebut sebagai bahan penyangga tanah. Tanah dengan kandungan bahan organik rendah akan berkurang kemampuannya mengikat pupuk kimia sehingga efisiensinya menurun akibat sebagian besar pupuk hilang melalui pencucian, fiksasi atau penguapan (Musnamar, 2007).

Salah satu sumber bahan organik adalah biochar. Biochar dapat berfungsi sebagai pembenah tanah, meningkatkan pertumbuhan tanaman dengan memasok sejumlah nutrisi yang berguna serta meningkatkan sifat fisik dan biologi tanah (Steiner, 2007).

Berdasarkan uraian di atas penulis tertarik melakukan penelitian untuk menganalisa respons pertumbuhan dan produksi tanaman jagung manis terhadap aplikasi biochar dan POC.

\section{BAHAN DAN METODE}

Penelitian ini dilaksanakan di lahan penelitian Balai Benih Induk Tanjung Selamat, jalan Pendidikan Kelurahan Tanjung Selamat, Kecamatan Medan Tuntungan, Medan pada ketinggian tempat $\pm 35 \mathrm{~m}$ dpl. Penelitian ini dilaksanakan pada bulan Oktober sampai dengan Desember 2016. Bahan - bahan yang digunakan pada penelitian ini ialah benih jagung manis varietas bonanza F1, biochar, pupuk organik cair, pupuk $\mathrm{N}$ (urea), pupuk $\mathrm{P}$ (SP-36), pupuk $\mathrm{K}(\mathrm{KCl})$, air dan Decis 2,5 EC. Alat - alat 
Tabel 1. Volume akar tanaman jagung umur 7 MST pada perlakuan biochar dan pupuk organik cair.

\begin{tabular}{|c|c|c|c|c|c|c|}
\hline \multirow{3}{*}{\multicolumn{2}{|c|}{$\begin{array}{l}\text { Pupuk Oganik } \\
\text { Cair (ml/l air) }\end{array}$}} & \multicolumn{4}{|c|}{ Biochar ( ton/ha ) } & \multirow{3}{*}{ Rataan } \\
\hline & & (Kontrol) & $(5)$ & $(10)$ & $(15)$ & \\
\hline & & $\mathrm{B} 0$ & B 1 & B 2 & B 3 & \\
\hline & & \multicolumn{5}{|c|}{ 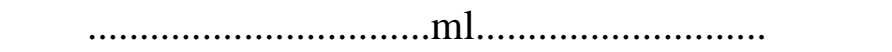 } \\
\hline \multicolumn{2}{|c|}{ ( Kontrol ) P0 } & 45,33 & 52,17 & 57,33 & 63,33 & $54,54 \mathrm{~b}$ \\
\hline$(5)$ & $\mathrm{P} 1$ & 46,33 & 53,33 & 60,33 & 63,67 & $55,92 \mathrm{~b}$ \\
\hline$(10)$ & $\mathrm{P} 2$ & 50,17 & 58,50 & 61,67 & 65 & $58,83 \mathrm{a}$ \\
\hline$(15)$ & $\mathrm{P} 3$ & 52 & 57,67 & 61,33 & 70,33 & $60,33 \mathrm{a}$ \\
\hline
\end{tabular}

$\begin{array}{lllll}\text { Rataan } & 48,46 \mathrm{c} & 55,42 \mathrm{~b} & 60,17 \mathrm{~b} & 65,58 \mathrm{a}\end{array}$

Keterangan: Angka-angka yang diikuti notasi yang berbeda pada kolom dan baris yang sama menunjukan perbedaan yang nyata pada Uji Duncantaraf $5 \%$.

yang digunakan pada penelitian ini ialah cangkul, meteran, pacak, plang nama, label, gembor, handsprayer, knapsack, timbangan analitik, oven, rol, jangka sorong, kalkulator, alat tulis dan alat-alat lainnya yang membantu penelitian ini.

$$
\text { Penelitian ini menggunakan }
$$

Rancangan Acak Kelompok (RAK) Faktorial dengan 2 faktor perlakuan. Faktor pertama adalah Konsentrasi Pupuk Organik Cair (P) dengan 4 taraf, yaitu; Kontrol (P0); $5 \mathrm{ml} /$ liter air (P1); $10 \mathrm{ml} /$ lliter air (P2); $15 \mathrm{ml} /$ liter air (P3) dan faktor kedua adalah Dosis Biochar (B) dengan 4taraf yaitu; Kontrol (B0); 5 ton / hektar (B1); 10 ton / hektar (B2); 15 ton / hektar (B3). Jika dari hasil analisis sidik ragam menunjukkan pengaruh yang nyata, maka dilanjutkan dengan Uji Beda Rataan berdasarkan Duncan Multiple Range Test (DMRT) pada taraf 5\%.

Pelaksanaan penelitian meliputi persiapan lahan, pengolahan tanah, persiapan benih,pembuatan biochar, pengaplikasian biochar, penanaman, pemupukan, pengaplikasian pupuk orgaik cair, pemeliharaan tanaman, dan panen. Peubah amatan yang diamati adalah tinggi tanaman dari 2 sampai 7 MST, luas daun, volume akar, bobot kering akar, bobot kering tajuk pada 7 MST, umur keluar bunga jantan, umur keluar bunga betina pada 8 MST, panjang tongkol, diameter tongkol, produksi per sampel dan produksi per plot pada $12 \mathrm{MST}$.

\section{HASIL DAN PEMBAHASAN}

\section{Respons Pertumbuhan Dan Produksi Tanaman Jagung Manis Terhadap Aplikasi Biochar}

Berdasarkan hasil analisis sidik ragam diketahui bahwa perlakuan biochar berpengaruh nyata terhadap peubah amatan volume akar, produksi per sampel dan produksi pe plot. Perlakuan biochar berpengaruh nyata terhadap peubah amatan volume akar (Tabel 1) tanaman pada 7 MST. Perlakuan biochar menghasilkan rataan volume akar tertinggi yaitu $66 \mathrm{ml}$ pada taraf B3 (15 ton/ha).

Lehmann and Joseph (2009) yaitu bahwa dalam tanah, biochar menyediakan habitat bagi mikroba tanah, biochar yang diaplikasikan dapat tinggal dalam tanah selama ratusan atau bahkan ribuan tahun. Dalam jangka panjang biochar tidak mengganggu keseimbangan karbon-nitrogen, tetapi bisa menahan dan menjadikan air dan nutrisi lebih tersedia bagi tanaman. bila digunakan sebagai pembenah tanah bersama pupuk organik dan anorganik, biochar dapat meningkatkan produktivitas, serta retensi dan ketersediaan hara bagi tanaman. Apliksasi biochar ke tanah dianggap sebagai suatu pendekatan yang baru dan unik untuk menjadikan suatu penampung (sink) bagi $\mathrm{CO} 2$ udara dalam jangka panjang pada ekosistem darat. 
Tabel 2. Produksi per sampel tanaman jagung umur 12 MST pada perlakuan biochar dan pupuk organik cair.

\begin{tabular}{|c|c|c|c|c|c|c|}
\hline \multirow{3}{*}{\multicolumn{2}{|c|}{$\begin{array}{l}\text { Pupuk Oganik } \\
\text { Cair (ml/l air) }\end{array}$}} & \multicolumn{4}{|c|}{ Biochar ( ton/ha ) } & \multirow{3}{*}{ Rataan } \\
\hline & & \multirow{2}{*}{$\begin{array}{c}\text { (Kontrol) } \\
\text { B } 0\end{array}$} & \multirow{2}{*}{$\begin{array}{l}5) \\
\text { B } 1 \\
\end{array}$} & \multirow{2}{*}{$\begin{array}{l}(10) \\
\text { B 2 }\end{array}$} & \multirow{2}{*}{$\begin{array}{l}(15) \\
\text { B 3 }\end{array}$} & \\
\hline & & & & & & \\
\hline & & & & ...g.. & & \\
\hline \multicolumn{2}{|c|}{ ( Kontrol ) P0 } & 246,67 & 266,67 & 273,33 & 293,33 & 270 \\
\hline ( 5 ) & $\mathrm{P} 1$ & 260,00 & 273,33 & 286,67 & 293,33 & 278,33 \\
\hline ( 10$)$ & $\mathrm{P} 2$ & 246,67 & 260 & 293,33 & 333,33 & 283,33 \\
\hline ( 15 ) & P3 & 253,33 & 260 & 313,33 & 333,33 & 290 \\
\hline
\end{tabular}

Keterangan: Angka-angka yang diikuti notasi yang berbeda pada baris yang sama menunjukan perbedaan yang nyata pada Uji Duncan taraf 5\%.

Perlakuan biochar menunjukkan pengaruh yang nyata terhadap peubah amatan produksi per sampel (Tabel 2) dan produksi per plot (Tabel 3) dengan rataan tertinggi yaitu 313,33 g untuk produksi per sampel dan rataan tertinggi yaitu $4750 \mathrm{~g}$ untuk produksi per plot pada taraf B3 (15 ton/ha). Hal ini diduga karena biochar pada taraf B3 (15 ton/ha) yang di aplikasikan ke tanah dapat membantu meningkatkan ketersediaan unsur hara sehingga mampu meningkatkan produktivitas tanaman jagung manis. Hal ini sesuai dengan pernyataan Brown (2009) bahwa penambahan biochar ke tanah meningkatkan ketersediaan fosfor, total nitrogen dan kapasitas tukar kation tanah (KTK) yang pada akhirnya meningkatkan hasil. Tingginya ketersediaan hara bagi tanaman merupakan hasil dari bertambahnya nutrisi secara langsung dari biochar, meningkatnya retensi hara, dan perubahan dinamika mikroba tanah. Keuntungan jangka panjangnya bagi ketersediaan hara berhubungan dengan stabilisasi karbon organik yang lebih tinggi seiring dengan pembebasan hara yang lebih lambat dibanding bahan organik yang biasa digunakan. Peran biochar terhadap peningkatan produktivitas tanaman dipengaruhi oleh jumlah yang ditambahkan. Pemberian sebesar 0,4-8 t/ha dilaporkan dapat meningkatan produktivitas secara nyata antara $20-40 \%$.

\section{Respons Pertumbuhan Dan Produksi Tanaman Jagung Manis Terhadap Aplikasi Pupuk Organik Cair}

Berdasarkan hasil analisis sidik ragam diketahui bahwa perlakuan pupuk organik cair berpengaruh nyata terhadap peubah amatan luas daun, volume akar dan produksi per plot tanaman jagung manis. Perlakuan pupuk organik cair berpengeruh nyata terhadap peubah amatan luas daun (Tabel 4) dan volume akar (Tabel 1) tanaman pada 7 MST. Perlakuan pupuk organik cair menghasilkan rataan luas daun tertinggi yaitu $812,46 \mathrm{~cm}^{2}$ dan rataan volume akar tertinggi yaitu $60 \mathrm{ml}$ pada taraf $\mathrm{P} 3$ (15 ml/l air). Hal ini diduga karena pupuk organik cair mengandung nitrogen, fosfor dan kalium yang mampu memperbaiki pertumbuhan vegetatif tanaman jagung manis. Hal ini sesuai dengan pernyataan Sari (2013) bahwa pupuk organik cair yang mengandung nitrogen, fosfor dan kalium mampu memperbaiki pertumbuhan vegetatif tanaman melalui peningkatan total luas daun dan jumlah klorofil yang dalam hal ini berhubungan langsung dengan proses fotosintesis dan peningkatan hasil produksi melalui akumulasi fotosintat pada biji. Perlakuan pupuk organik cair menunjukkan pengaruh yang nyata terhadap peubah amatan produksi per plot (Tabel 3) dengan rataan tertinggi yaitu $5225 \mathrm{~g}$ pada taraf P3 (15 ml/l air). 
Tabel 3. Produksi per plot tanaman jagung umur 12 MST pada perlakuan biochar dan pupuk organik cair.

\begin{tabular}{|c|c|c|c|c|c|c|}
\hline \multirow{3}{*}{\multicolumn{2}{|c|}{$\begin{array}{c}\text { Pupuk } \\
\text { Oganik Cair } \\
\text { (ml/1 air) }\end{array}$}} & \multicolumn{4}{|c|}{ Biochar ( ton/ha ) } & \multirow{3}{*}{ Rataan } \\
\hline & & (Kontrol) & (5) & (10) & $(15)$ & \\
\hline & & B 0 & B 1 & B 2 & B 3 & \\
\hline & & & & ....g. & & \\
\hline \multicolumn{2}{|c|}{ ( Kontrol ) P0 } & 3433,33 & 3633,33 & 3700 & 4000 & $3692 \mathrm{c}$ \\
\hline$(5)$ & P1 & 3700 & 3833,33 & 3966,67 & 4433,33 & $3983,33 \mathrm{c}$ \\
\hline$(10)$ & $\mathrm{P} 2$ & 4533,33 & 4700 & 4833,33 & 4933,33 & $4750 \mathrm{~b}$ \\
\hline$(15)$ & P3 & 4866,67 & 5067 & 5333,33 & 5633,33 & $5225 \mathrm{a}$ \\
\hline \multicolumn{2}{|c|}{ Rataan } & $4133,33 \mathrm{~b}$ & $4308 \mathrm{~b}$ & $4458,33 \mathrm{a}$ & $4750 \mathrm{a}$ & \\
\hline
\end{tabular}

Keterangan: Angka-angka yang diikuti notasi yang berbeda pada kolom dan baris yang sama menunjukan perbedaan yang nyata pada Uji Duncan taraf $5 \%$.

Hal ini diduga karena penggunaan pupuk organik cair cepat diserap oleh tanaman sehingga mampu meningkatkan produksi tanaman jagung manis. Hal ini sesuai dengan pernyataan Salisbury dan Ross (1995) bahwa proses penyerapan hara melalui daun terjadi karena adanya proses difusi dan osmosis melalui stomata sehingga mekanismenya berhubungan langsung dengan membuka dan menutupnya stomata. Penyerapan air oleh sel penjaga disebabkan oleh perbedaan potensial osmotic antara sel penjaga dan sel- sel di sekitarnya. Jika potensial osmotik protoplas sel penjaga lebih rendah dari pada sel sekitarnya, maka air akan bergerak masuk ke dalam sel penjaga secara osmosis yang selanjutnya akan mengakibatkan naiknya tekanan sel, kemudian sel mengembun. Setelah stomata membuka, unsur hara dalam bentuk ion- ion yang berada pada permukaan daun akan bergerak masuk secara difusi dan osmosis ke dalam sel. Masuknya ion- ion tersebut ke dalam sel tanaman terjadi secara bertahap melalui beberap lapisan bahan- bahan yang berbeda. Mula- mula molekul dan ion- ion zat terlarut menembus lapisan yang menyelubungi permukaan dinding sel sebelah luar dengan proses difusi, laju menuju dinding sel yang dilapisi oleh membran plasma yang bersifat impermeabel terhadap ion- ion. Setelah melalui membran plasma, ion- ion masuk ke dalam sitoplasma. 
Tabel 4. Luas daun tanaman jagung umur 7 MST pada perlakuan biochar dan pupuk organik cair.

\begin{tabular}{|c|c|c|c|c|c|c|}
\hline \multirow{3}{*}{\multicolumn{2}{|c|}{$\begin{array}{l}\text { Pupuk Oganik } \\
\text { Cair (ml/1 air) }\end{array}$}} & \multicolumn{4}{|c|}{ Biochar ( ton/ha ) } & \multirow{3}{*}{ Rataan } \\
\hline & & (Kontrol) & (5) & (10) & (15) & \\
\hline & & B 0 & B 1 & B 2 & B 3 & \\
\hline & & \multicolumn{5}{|c|}{ 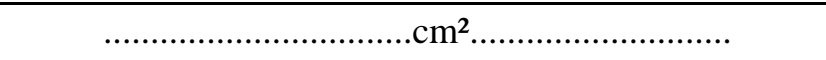 } \\
\hline \multicolumn{2}{|c|}{ ( Kontrol ) $\mathrm{P}_{0}$} & 760,04 & 769,77 & 725,73 & 792,94 & $762,12 b$ \\
\hline ( 5 ) & $\mathrm{P}_{1}$ & 794,05 & 804,35 & 793,74 & 767,41 & $789,89 \mathrm{a}$ \\
\hline ( 10$)$ & $\mathrm{P}_{2}$ & 786,61 & 790,78 & 834,93 & 762,43 & $793,69 \mathrm{a}$ \\
\hline ( 15$)$ & $\mathrm{P}_{3}$ & 800,99 & 822,28 & 838,65 & 787,94 & 812,46 a \\
\hline \multicolumn{2}{|c|}{ Rataan } & 785,42 & 796,80 & 798,26 & 777,68 & \\
\hline
\end{tabular}

Keterangan: Angka-angka yang diikuti notasi yang berbeda pada kolom yang sama menunjukan perbedaan yang nyata pada Uji Duncan taraf $5 \%$.

Di dalam sitoplasma, molekul dan ionion tersebut mengalami beberapa kemungkinan: diubah ke dalam bentuk lain, langsung mengalami pengangkutan ke sel lain, dan diangkut oleh tonoplas menuju vakuola atau organel- organel lain dalam sitoplasma antara lain mitokondria dimana terjadi proses respirasi sehingga dapat berperan dalam pertumbuhan tanaman (Prawiranata et al., 1981).

Suriadikarta dan Simanungkalit (2006) menyatakan bahwa bahan yang terkandung dalam pupuk organik cair sangat bermanfaat bagi peningkatan produksi pertanian baik kualitas maupun kuantitas, mengurangi pencemaran lingkungan, dan meningkatkan kualitas tanah secara berkelanjutan. Penggunaan pupuk organik dalam jangka panjang dapat meningkatkan produktivitas lahan dan dapat mencegah degradasi lahan.

\section{Respons Pertumbuhan Dan Produksi Tanaman Jagung Manis Terhadap Interaksi Aplikasi Biochar Dan Pupuk Organik Cair}

Berdasarkan hasil analisis sidik ragam diketahui bahwa interaksi perlakuan biochar dan pupuk organik cair berpengaruh tidak nyata terhadap semua peubah amatan. Hal ini diduga karena perlakuan biochar dan perlakuan pupuk organik cair memiliki cara kerja dan lokasi aplikasi yang berbeda untuk meningkatkan pertumbuhan dan produksi tanaman sehingga tidak terwujud interaksi antara kedua perlakuan tersebut. Biochar bekerja di dalam tanah dengan cara membantu memperbaiki sifat tanah serta menjadi pembenah tanah. Hal ini sesuai dengan pernyataan Lehmann and Joseph (2009) bahwa biochar merupakan bahan ameliorant tanah yang diaplikasikan langsung ke tanah. Biochar dapat memperbaiki kondisi tanah dan meningkatkan produksi tanaman, terutama pada tanah-tanah yang kurang subur. Kemampuan biochar untuk memegang air dan hara dalam tanah membantu mencegah terjadinya kehilangan pupuk akibat aliran permukaan (run off) dan pencucian (leaching) (BPTP 2011), sedangkan pupuk organik cair bekerja sebagai nutrisi didalam tubuh tanaman setelah diserap melalui stomata pada tubuh tanaman. Hal ini sesuai dengan pernyataan Sari (2008) yaitu bahwa pupuk organik cair kebanyakan diaplikasikan melalui daun atau disebut sebagai pupuk cair foliar yang mengandung hara makro dan mikro esensial (N, P, K, S, Ca, Mg, B, Mo, Cu, Fe, Mn, dan bahan organik). Hal ini mendukung bahwa perlakuan biochar dan perlakuan pupuk organik cair tidak mengalami interaksi karena memiliki cara kerja dan lokasi aplikasi yang berbeda untuk meningkatkan pertumbuhan dan produksi tanaman. Tidak terjadinya perpaduan atau interaksi antara aplikasi biochar dan pupuk organik cair dapat dilihat dari tidak terjadinya perubahan taraf faktor perlakuan 
biochar pada saat perubahan taraf faktor pupuk organik cair. Hal ini sesuai dengan literatur Gomez and Gomez (1984) yang menyatakan bahwa dua faktor dikatakan berinteraksi apabila pengaruh sederhana suatu faktor berubah pada saat perubahan taraf faktor lainnya berubah.

\section{SIMPULAN DAN SARAN}

Pemberian biochar berpengaruh nyata terhadap volume akar, produksi per sampel dan produksi per plot. Aplikasi biochar terbaik ialah pada dosis 15 ton/ha. Perlakuan pupuk organik cair berpengaruh nyata terhadap luas daun, volume akar dan produksi per plot. Aplikasi pupuk organik cair terbaik ialah pada konsentrasi $15 \mathrm{ml} / \mathrm{l}$ air. Interaksi antara perlakuan pupuk organik cair dan perlakuan biochar berpengaruh tidak nyata terhadap semua peubah amatan. Saran untuk meningkatkan pertumbuhan dan produksi tanaman jagung manis dapat memanfaatkan biochar sebanyak 15 ton/ha atau aplikasi pupuk organik cair dengan dosis $15 \mathrm{ml} / \mathrm{l}$ air

\section{DAFTAR PUSTAKA}

BPPP. 2008. Teknologi budidaya jagung. Badan Penelitian dan Pengembangan Pertanian. Bogor.

BPTP. 2011. Arang Hayati (BIOCHAR) sebagai Bahan Pembenah Tanah. Edisi Khusus Penas XIII, 22 Juni 2011.

Brown, R., 2009. Biochar Production Technology. In: Biochar forEnvironmental Management: Scienceand Technology (Eds). J.

Gomez, K.A and A.A. Gomez, 1984. Prosedur Statistik Untuk Penelitian Pertanian. Diterjemahkan Oleh Endang Syamsuddin dan Justika S. Baharsyah. UI-Press. Jakarta.

Hasibuan, B. E. 2006. Pupuk dan Pemupukan. Fakultas Pertanian USU. Medan.

Lehmann J. \& S. Joseph, 2009. Biochar for Environmental Management. First published by Earth scan in the UK and USA in 2009. P416.
Musnamar, E.I., 2007. Pupuk Organik Cair dan Padat, Pembuatan, Aplikasi. Penebar Swadaya, Jakarta.Hlm 1-4.

Novizan, 2001. Petunjuk Pemupukan Yang Efektif. Agromedia Pustaka. Tanggerang.

Prawiranata, W., S. Harran dan Tjondronegoro. 1981. Dasar-dasar Fisiologi Tumbuhan. Fakultas Pertanian IPB, Bogor.

Purwono dan R. Hartono. 2007. Bertanam jagung unggul, dalam Bara, A. dan M.A. Chozin (Ed.) Makalah Seminar Departemen Agronomi danHortikultura, Vol. 2.

Salisbury, F. B. dan C. W. Ross. 1995. Fisiologi Tumbuhan, Perkembangan Tumbuhan, dan Fisiologi Lingkungan. Institut Teknologi Bandung, Bandung.

Sari, D. 2008. Pengaruh Beberapa Pupuk Organik Terhadap Pertumbuhan Dan Serapan N Serta P Tanaman Petsai (Brassica Pekinensis) Dan Brokoli (Brassica Oleracea) Pada Andisol Cisarua. Skripsi. Program Studi Ilmu Tanah, IPB, Bogor.

Sari, D. K., 2013. Respons Pertumbuhan dan Produksi Beberapa Varietas Kedelai (Glycine $\max ($ L.) Merril) dengan Pemberian Pupuk Cair.Skripsi. Universitas Sumatera Utara.

Simamora, Ir. S dan Salundik.2006. Meningkatkan Kualitas Kompos. AgroMedia Pustaka, Jakarta.

Steiner, C., 2007. Slash and Char as Alternative to Slash and Burn: Soil Charcoal Amendments Maintain Soil Fertility and Establish a Carbon Sink.Cuvillier Verlag, Gottingen.

Suriadikarta, D.A. dan R.D.M, Simanungkalit.2006. Pupuk Organik dan Pupuk Hayati.Balai Besar Penelitian dan Pengembangan Sumber daya Lahan Pertanian. Bogor. 283 hal.

Suyamto, Zubachtirodin, M.S. Pabbage, dan S. Saenong. 2006. Pengeloaan tanaman terpadu (PTT). Badan Penelitian dan Pengembangan Pertanian. Bogor. 
